Article

\title{
The Effect of an Engineered Biostimulant Derived from Ascophyllum nodosum on Grass Yield under a Reduced Nitrogen Regime in an Agronomic Setting
}

\author{
Patrick Quille ${ }^{1,2}$, Aisling Claffey ${ }^{3} \mathbb{D}$, Ewan Feeney ${ }^{4}$, Joanna Kacprzyk ${ }^{2,5,6} \mathbb{D}$, Carl K.-Y. Ng ${ }^{2,5,6}{ }^{\mathbb{D}}$ \\ and Shane $\mathrm{O}^{\prime}$ Connell ${ }^{1,4, *(\mathbb{D})}$
}

1 Shannon Applied Biotechnology Centre, Plant Biostimulant Group, Munster Technological University-Kerry, V92 CX88 Tralee, Ireland; patrick.quille@mtu.ie

2 School of Biology and Environmental Science, University College Dublin, Belfield, D04 N2E5 Dublin, Ireland; joanna.kacprzyk@ucd.ie (J.K.); carl.ng@ucd.ie (C.K.-Y.N.)

3 J. Grennans \& Sons, Rath, Birr, R42 YA49 Offaly, Ireland; aisling.claffey@grennans.ie

4 Brandon Bioscience, V92 P2FE Tralee, Ireland; efeeney@brandonbioscience.com

5 Centre for Plant Science, University College Dublin, Belfield, D04 N2E5 Dublin, Ireland

6 Earth Institute, University College Dublin, Belfield, D04 N2E5 Dublin, Ireland

* Correspondence: shane.oconnell@mtu.ie

check for

updates

Citation: Quille, P.; Claffey, A.;

Feeney, E.; Kacprzyk, J.; Ng, C.K.-Y.; O'Connell, S. The Effect of an Engineered Biostimulant Derived from Ascophyllum nodosum on Grass Yield under a Reduced Nitrogen Regime in an Agronomic Setting. Agronomy 2022, 12, 463. https:// doi.org/10.3390/agronomy12020463 Academic Editors: Youssef Rouphael and Giuseppe Colla

Received: 10 January 2022

Accepted: 8 February 2022

Published: 13 February 2022

Publisher's Note: MDPI stays neutral with regard to jurisdictional claims in published maps and institutional affiliations.

Copyright: (C) 2022 by the authors. Licensee MDPI, Basel, Switzerland. This article is an open access article distributed under the terms and conditions of the Creative Commons Attribution (CC BY) license (https:// creativecommons.org/licenses/by/ $4.0 /)$.

\begin{abstract}
Nitrogen $(\mathrm{N})$ is the most important macronutrient used in modern agricultural systems to enhance crop yields; however, a significant amount of applied $\mathrm{N}$ is not taken up by the crop and is lost to the environment. Improving the nitrogen use efficiency (NUE) of crops can curb these environmental losses while concurrently delivering economic gains. Plant biostimulants have potential to improve NUE in agronomic settings. In this research, a granular N-containing fertilizer coated with the biostimulant PSI-362, an extract from the brown seaweed Ascophyllum nodosum, was applied to grass managed under different production systems to assess its impact on NUE. The role of soil type, $\mathrm{pH}$, phosphorus $(\mathrm{P})$ and potassium $(\mathrm{K})$ on the efficacy of the biostimulant in improving NUE was assessed using lysimeters filled with six different soils. A significant increase in grass yield (29\%) was found with PSI-362 addition at a 75\% N rate over the $75 \% \mathrm{~N}$ control (8478 $\mathrm{kg}$ of dry matter $(\mathrm{DM}) \mathrm{ha}^{-1}$ vs. $6772 \mathrm{~kg}$ of $\mathrm{DM} \mathrm{ha}^{-1}$ ) over two years of trials under a simulated grazing platform of six rotations. The NUE increased to $96.6 \%$ for the PSI-362-treated grass compared to $82.8 \%$ for controls. Field-based evaluations demonstrated no decrease in yield and quality from harvested and grazed grass treated with the biostimulant when the $\mathrm{N}$ rate was reduced by 20 to $25 \%$. Based on these results, the application of PSI-362 allows a reduction in nitrogen input by up to $25 \%$ without losses of grass yield or quality.
\end{abstract}

Keywords: nitrogen use efficiency; Ascophyllum nodosum; nitrogen reduction; grassland productivity; environment; sustainability; biostimulant

\section{Introduction}

Just over a century ago, the Haber-Bosch process allowed nitrogen (N) to be synthetically produced on an industrial scale, enabling the beginnings of modern agriculture and thus the ability of the planet to support its current population. $\mathrm{N}$ is the most significant of the macronutrients in terms of the amount applied to the soil and its influence on crop yield and quality. The $\mathrm{N}$ application rate depends on a number of factors such as crop type and agronomic system; for example, in Ireland, the application rate of $\mathrm{N}$ to grassland can vary from $40 \mathrm{~kg} \mathrm{ha}^{-1}$ to $306 \mathrm{~kg} \mathrm{ha}^{-1}$ depending on the stocking rate [1]. It is also an expensive input for farmers, representing up to one fifth of all direct costs in some production systems [2]. $\mathrm{N}$ mineral fertilizers have a large carbon footprint due to the intensive energy requirement for their production along with their transportation costs. The carbon footprint 
can range from $3.5 \mathrm{~kg} \mathrm{CO} 2 \mathrm{eq} / \mathrm{kg}$ nitrogen to almost $12 \mathrm{~kg} \mathrm{CO} 2 \mathrm{eq} / \mathrm{kg}$ nitrogen for calcium ammonia nitrate (CAN) depending on the region of manufacture and energy source [3]. Additional negative environmental impacts of $\mathrm{N}$ use include acidification of soils [4] and the degradation of water quality (in the form of nitrate; $\mathrm{NO}_{2}{ }^{-}$) and air quality [5]. The two main air pollutants from $\mathrm{N}$ fertilization are $\mathrm{NH}_{3}$ (ammonia) and $\mathrm{N}_{2} \mathrm{O}$ (nitrous oxide). $\mathrm{NH}_{3}$ contributes to the acidification of soils and watercourses leading to losses in biodiversity [6], while $\mathrm{N}_{2} \mathrm{O}$ is a potent greenhouse gas, with almost 300 times more warming ability than $\mathrm{CO}_{2}$. Globally, $\mathrm{N}_{2} \mathrm{O}$ is responsible for $38 \%$ of all direct agricultural emissions [7].

Nitrogen use efficiency (NUE), in agronomic terms, is defined as the percentage of $\mathrm{N}$ applied to the soil that is taken up by the crop [8,9]. NUE is dependent on many factors, ranging from the amount of $\mathrm{N}$ applied, the timing of application, type of $\mathrm{N}$ applied, soil and environmental conditions, to the type and variety of crop [10]. Values for NUE will vary from crop to crop, across regions and between agronomic systems. Estimates for NUE can range from 25 to $80 \%$, thus representing a potential significant loss of $\mathrm{N}$ to the environment [11]. Zemenchik and Albrecht (2002) investigated N application rates on three varieties of grasses (Kentucky bluegrass, smooth bromegrass and orchardgrass) where they found a $\mathrm{N}$ recovery of 0.15 to 0.5 (15 to 50\% NUE), while [12] reported NUE varying from 63 to $87 \%$ across various compounded mineral fertilizers in perennial ryegrass. Additionally, environmental conditions, $\mathrm{N}$ levels and split applications were observed to exert a significant effect on NUE on permanent grasslands for first-cut silage [13].

Plant biostimulants are legally defined within the EU fertilizer regulation 2019/1009 as "any product stimulating plant nutrition processes independently of the product's nutrient content, with the aim of improving one or more of the following characteristics of the plant: nutrient use efficiency, tolerance to abiotic stress, crop quality traits or availability of confined nutrients in the soil and rhizosphere" [14]. Plant biostimulant products can be classified under a number of categories based on the origin of the raw material used in their manufacture, e.g., seaweed extracts and plant/animal protein hydrolysates, etc. [15]. Traditionally, agronomic research involving biostimulants has focused on enhancing the plant's ability to overcome abiotic stress leading to improved yield and/or quality. In recent years, there has been an increased interest in investigating their effects on nutrient use efficiency [16,17], driven in part through various initiatives such as the European Commission's Biodiversity Strategy, where a key goal is a $20 \%$ reduction in fertilizer use [18]. Goñi et al. [19] previously reported that under a 75\% N regime, a biostimulant-coated granular fertilizer increased NUE in barley by 30-60\%. The increased NUE may be attributed to an increased uptake of nitrate (17 to $72 \%$ over control plants) that was associated with upregulation of the expression of root nitrate transporters (NRT 1.1, NRT 2.1 and NRT 1.5). The aim of this study was to evaluate the effectiveness of a biostimulant, PSI-362, derived from the brown seaweed, Ascophyllum nodosum, on a range of grass production systems to maintain yield and quality with a reduced N (20-25\% reduction) fertilizer application regime. The co-application of mineral $\mathrm{N}$ fertilizer and a plant biostimulant as reported here is suitable for implementation in current agronomic practice and is aligned with best practice, with regard to timing of granular fertilizer application at key growth stages and optimal environmental conditions. Grass systems ranged from open lysimeter trials with different soils to large-scale field trials (pasture grazing trials and silage harvesting trials) at 13 sites conducted in 2020 and 2021, where there was no loss in grass quality or yield when treated with PSI-362 under a reduced nitrogen regime.

\section{Materials and Methods}

\subsection{PSI-362-Coated Granular N Fertilizer}

Granular fertilizer was coated with the biostimulant PSI-362 (an alkaline liquid seaweed extract biostimulant from the brown seaweed, Ascophyllum nodosum, engineered using a proprietary process and supplied by Brandon Bioscience, Ireland) at three different rates: $0.5 \times, 1.0 \times$ and $1.5 \times$ (the $1.0 \times$ rate refers to the rate for commercially available products). The compositional analysis of PSI-362 was previously reported by [19]. For the purposes of 
this study, the $\mathrm{N}$ content was found to be $0.4 \% \mathrm{w} / \mathrm{v}$ (ranging from $0.8 \mathrm{~g} \mathrm{ha}^{-1}$ to $2.4 \mathrm{~g} \mathrm{ha}^{-1}$ depending on the application rate) while the carbon content of the applied biostimulant ranged from $40 \mathrm{~g}$ to $120 \mathrm{~g}$ per hectare depending on the application rate. Target Fertilizers (Enniscorthy, Ireland) supplied all granular fertilizers used in the study.

\subsection{Modified Lysimeter Grass Trial Setup}

The objective of the lysimeter trials was to assess the effectiveness of three rates of biostimulant coated on mineral $\mathrm{N}$ fertilizer applied to a ryegrass sward at a reduced $\mathrm{N}$ rate $(75 \% \mathrm{~N})$ versus no biostimulant at a $75 \% \mathrm{~N}$ rate and no biostimulant at a $100 \% \mathrm{~N}$ rate on biomass dry matter (DM) accumulation. The experiment was setup to simulate a rotational pasture grazing system with six different soils classified into two different soil types. The six different soils $(2 \times$ loam and $4 \times$ silt-loam) were collected from the Kerry, Cork and Tipperary regions of Ireland (each soil type corresponded to a single location) in 2013. Each treatment had three lysimeter replicates for each of the six soils. Soils were classified in terms of their sand, silt and clay contents (Supplementary Table S1) using the dispersion (sodium hexametaphosphate method) PSD test [20]. The modified lysimeters (Supplementary Figure S1) were filled by placing $30 \mathrm{~kg}$ of soil (taken from the A horizon to a max. depth of $45 \mathrm{~cm}$ ) into a 20-litre lysimeter (surface area of $0.003 \mathrm{~m}^{2}$ per lysimeter). To ensure adequate drainage, a grommet was placed at the bottom of the lysimeter, over which a layer of coarse sand and pea gravel was added (about 2 to 3 inches) before the soils were added on top. All soils were kept under permanent pasture until 2019 when reseeding commenced with a commercial grass seed mixture (Diamond Hi Digestibility supplied by Kellihers Feed and Agricultural Supplies, Tralee, Co., Kerry, Ireland) applied at a rate of $34.6 \mathrm{~kg} \mathrm{ha}^{-1}$ (or $14 \mathrm{~kg}$ acre ${ }^{-1}$ ) in September 2019. The grass seed mixture contained perennial rye grass (Lolium perenne) varieties: Astonenergy (29\%), Meiduno (23\%), Oakpark (21\%), Astonking (21\%) and white clover (Trifolium repens): Crusader (6\%).

\subsection{Lysimeter Soil Nutrient Analysis}

Prior to experiments beginning in 2020, all soils were analyzed for $\mathrm{pH}$ using the SMP buffer test and P and K contents via Morgan's extraction method using colorimetric and atomic spectroscopy, respectively [21]. This analysis was performed by Southern Scientific Services (Farranfore, Co., Kerry, Ireland; Supplementary Table S1).

\subsection{Grass Growth Rate, Yield Measurement and Quality Assessment}

The lysimeter trials ran from June to October in 2020 and from March to August in 2021. At the beginning of both years, grass in all lysimeters was cut to a height of 4 to $6 \mathrm{~cm}$ from the soil level. Fertilizer was applied according to the rates listed in Supplementary Table S2. Application rates were based on an intensive livestock system stocked at rates of 2.47 livestock units ha ${ }^{-1}$ [1]. The grass growing period per rotation ranged from 18 to 30 days depending on seasonal growth rates. Grass in lysimeters was harvested at the 3-leaf growth stage $\left(\approx 1200\right.$ to $\left.1600 \mathrm{~kg} \mathrm{DM} \mathrm{ha}^{-1}\right)$ to simulate maximum utilization efficiency under a pasture grazing system leaving a residual of 4 to $6 \mathrm{~cm}$ in height [22]. Grass was collected after each harvest/rotation in a plastic bag, weighed immediately to calculate yield and subsequently reported as $\mathrm{kg} \mathrm{DM} \mathrm{ha}^{-1}$. Dry weight (DW) was calculated by taking representative samples after each harvest and drying these overnight in a convection oven at $100{ }^{\circ} \mathrm{C}$. The growth rate was reported as $\mathrm{kg} \mathrm{DM} \mathrm{ha}^{-1} \mathrm{day}^{-1}$ and was calculated by dividing the DM yield per rotation by the number of days since the last harvest. Samples were also taken for the determination of crude protein (CP) and dry matter digestibility (DMD) at two timepoints in 2020 (June and September) and 2021 (April and June). CP was determined using a N analyzer (Leco CNS 928 Analyzer) and scanning via NIRS (near infrared spectroscopy) to predict DMD. This analysis was carried out by Southern Scientific Services (Farranfore, Co., Kerry, Ireland). Subsequent to harvesting, fertilizer was applied to all lysimeters within $48 \mathrm{~h}$ according to rates listed in Supplementary Table S2, once again to simulate typical agronomic activity, before the pasture cycle continued once 
more. Fertilizer was applied as calcium ammonium nitrate (CAN) $(27 \% \mathrm{~N}+4 \% \mathrm{~S})$; the control received $100 \%$ of recommended $\mathrm{N}$, while treatments (with/without biostimulant) received $25 \%$ less $\mathrm{N}(75 \% \mathrm{~N})$. Nitrogen use efficiency (NUE) was calculated by subtracting the determined $\mathrm{N}$ in grass from the unfertilized lysimeters $\left(\mathrm{N}_{0}\right)$ from the determined $\mathrm{N}$ in the various treated lysimeters $\left(\mathrm{N}_{\mathrm{x}}\right)$, and dividing this figure by $\mathrm{kg}$ of $\mathrm{N}$ applied: [(grass yield at $\mathrm{N}_{\mathrm{x}}-$ grass yield at $\mathrm{N}_{0}$ ) $/ \mathrm{kg}$ of $\mathrm{N}$ applied at $\left.\mathrm{N}_{\mathrm{x}}\right] \times 100$ [23].

\subsection{Silage Harvesting Field Trials}

In order to assess the success of PSI-362 under typical agronomic systems, silage harvesting and pasture grazing trials were conducted where areas treated with PSI-362 received up to $25 \%$ less $\mathrm{N}$ and were compared to a $100 \% \mathrm{~N}$ control for that farm, in terms of grass DM yield, DMD and CP.

Silage harvesting field trials were conducted across five sites (five farms) in 2020 and six sites (six farms) in 2021 (trial site coordinates and weather data are available in Supplementary Tables S3 and S4). Soil sampling was carried out at all sites within the previous 12 months with $\mathrm{P}$ and $\mathrm{K}$ levels being determined as described previously. All trials in 2020 were third-cut grass silage trials, while trials in 2021 were a mixture of first (two trials), second (three trials) and third (one trial) cuts. Nitrogen was applied to treated areas in 2020 via a coated (coated at the $1 x$ concentration of PSI-362) CAN (27\% N + 4\% S) granular fertilizer, while the control areas received $\mathrm{N}$ in the form of CAN $(27 \% \mathrm{~N}+4 \% \mathrm{~S})$ at the appropriate higher rate as stated in Supplementary Table S4 (100\% vs. $80 \%$ N). For farm $5, \mathrm{~N}$ was also applied in the form of organic manure at a rate of $9 \mathrm{~kg} \mathrm{~N} \mathrm{ha}^{-1}$ for both control and treated sites. According to Wall and Plunkett [1], the inorganic nitrogen requirement will depend on the application of organic $\mathrm{N}$, age of the sward, grazing and fertilizer history as well as environmental conditions, and is typically $125 \mathrm{~kg} \mathrm{ha}^{-1}$ for first-cut silage and $100 \mathrm{~kg} \mathrm{ha}^{-1}$ for subsequent cuts, indicating that the $100 \% \mathrm{~N}$ control did not exceed these rates (Supplementary Table S3).

For the 2021 field trials, a compound fertilizer (a fertilizer that contains nitrogen, phosphorous and potassium (N-P-K)) was coated with the biostimulant PSI-362 (20-2-12 + 3 S; $\mathrm{N}-\mathrm{P}-\mathrm{K}+\mathrm{S})$ and applied to treated areas while control $(100 \% \mathrm{~N})$ areas received either $24-2.5-$ $10+3 \mathrm{~S}$ or $21-2 \cdot 2-10+3 \mathrm{~S}(\mathrm{~N}-\mathrm{P}-\mathrm{K}+\mathrm{S})$ at appropriate rates (see Supplementary Table S3). Farms 1 and 2 (both first-cut silage trials) also received $\mathrm{N}$ in the form of organic manure at a rate of $12 \mathrm{~kg} \mathrm{~N} \mathrm{ha}^{-1}$, while farm 3 (second cut) received $9 \mathrm{~kg} \mathrm{~N} \mathrm{ha}^{-1}$ from organic manure. All trial sites have been under permanent pasture (perennial ryegrass, Lolium perenne L.) for at least three years except farm 11 from the 2021 trial, which was reseeded in 2020. Yield was calculated on the day of harvest via the cut and weigh technique [24]. Samples were also taken and analyzed for \% DM, DMD and CP by near infrared spectroscopy at FBA laboratories (Cappoquin, Co., Waterford, Ireland). In first-cut silage trials from $2021(n=2)$, samples for DMD and CP were taken and analyzed three weeks prior to harvesting of both sites. Samples for DMD and CP for second-cut silage trials were taken and analyzed two weeks prior to harvesting in 2021. In third-cut silage trials from $2020(n=5)$ and 2021 $(n=1)$, samples for DMD and CP were taken and analyzed five days prior to harvesting.

\subsection{Grazing Field Trials}

Grazing field trials were conducted across two different sites in 2021. Site 1 is located at Shanntallow, Moneymore, Co., Galway, Ireland $\left(53^{\circ} 16^{\prime} 15.9^{\prime \prime} \mathrm{N} 8^{\circ} 50^{\prime} 42.5^{\prime \prime} \mathrm{W}\right)$, and site 2 is located at Ahabeg, Co., Kerry, Ireland $\left(52^{\circ} 24^{\prime} 37^{\prime \prime} \mathrm{N} 9^{\circ} 40^{\prime} 14^{\prime \prime} \mathrm{W}\right)$. All paddocks at site 1 have been under permanent pasture since 2018, while paddocks at site 2 were reseeded in 2020 and 2021. The $\mathrm{pH}$ ranged from 6.2 to 6.6 for site 1 over the 34 individual paddocks used in the study. No paddock at site 1 had a $\mathrm{P}$ and $\mathrm{K}$ index less than 3 for both nutrients, while $\mathrm{pH}$ at site 2 was 6.6 with a $\mathrm{P}$ and $\mathrm{K}$ index of 3 and 4 , respectively. Both farms were growing a perennial ryegrass mixture, including varieties Aston Energy, Oakpark, Meiduno, Alfonso and Glenviegh at site 1 (here all fields had a 5\% white clover variety ((Trifolium repens; Crusader). Site 2 a 50:50 mixture of tetraploid: diploid (Abergain and 
Aberchoice). Treated areas received $75 \% \mathrm{~N}$ in the form of PSI-362-coated CAN $(22 \% \mathrm{~N}+4 \%$ S) while control areas received $100 \% \mathrm{~N}$ rate in the form of CAN $(27 \% \mathrm{~N}+4 \% \mathrm{~S})$ at site 1 and protected urea $(46 \% \mathrm{~N}$ containing the urease inhibitors NBPT (N-(n-butyl)thiophosphoric triamide) and NPPT (N-(n-propyl) thiophosphoric triamide)) at site 2. Grazing ran from May until August at site 1 and from May until July at site 2. Rates for the $100 \% \mathrm{~N}$ control were $56 \mathrm{~kg} \mathrm{ha}^{-1}$ in May and $24 \mathrm{~kg} \mathrm{ha}^{-1}$ for subsequent months, with the $75 \% \mathrm{~N}$ treatment receiving the appropriate reduced amounts. At both farms, grass was measured twice weekly utilizing the cut and weigh technique [24], and daily growth rates were calculated and inputted into Pasturebase Ireland [25]. Samples for analysis of DMD and CP were taken in June and July from crops just prior to grazing $\left(\approx 1200\right.$ to $\left.1500 \mathrm{~kg} \mathrm{DM} \mathrm{ha}^{-1}\right)$ and were analyzed as described previously by FBA laboratories (Cappoquin, Co., Waterford, Ireland) for the pasture at site 1 only.

\subsection{Weather Data}

Supplementary Table S4 describes the rainfall and mean $10 \mathrm{~cm}$ soil temperature for all field sites. Weather information was gathered from the nearest (within 20 miles) Met Eireann (The Irish Meteorological Service) weather station relevant to the individual sites. Where available, the long-term averages (LTAs) over the preceding 30 years were included.

The lysimeter trials ran from June to October in 2020 and from February to August in 2021. The mean soil temperature at $10 \mathrm{~cm}$ depth from June to October in 2020 was $14.5^{\circ} \mathrm{C}$, with a total rainfall in this period of $591 \mathrm{~mm}$. In 2021, the mean soil temperature from February to August was $12.2{ }^{\circ} \mathrm{C}$, with a total rainfall during this time of $626 \mathrm{~mm}$.

In 2020, for the silage harvesting trials, sites 1, 2 and 3 received $240 \mathrm{~mm}$ of rain over the months of July and August (the LTAs were $157 \mathrm{~mm}$, representing a $53 \%$ increase in rainfall over these months), with an average $10 \mathrm{~cm}$ soil temperature of $15.7^{\circ} \mathrm{C}$, while sites 4 and 5 received $230 \mathrm{~mm}$ of rain (the LTA was $194 \mathrm{~mm}$, representing a 19\% increase in rainfall over these months), with a mean $10 \mathrm{~cm}$ soil temperature of $15.6^{\circ} \mathrm{C}$ over the trial period. In 2021, field sites 6,7 and 8 received $132.9 \mathrm{~mm}$ of rain, a value that is broadly in line with the LTA $(135.1 \mathrm{~mm})$, with a mean $10 \mathrm{~cm}$ soil temperature of $9.2^{\circ} \mathrm{C}$ in May and June; site 10 received $83.5 \mathrm{~mm}$ of rain (LTA of $147 \mathrm{~mm}$ ), with a mean $10 \mathrm{~cm}$ soil temperature of $15.6{ }^{\circ} \mathrm{C}$ over the months June and July; and site 11 received $217 \mathrm{~mm}$ of rain (a $38 \%$ decrease relative to the LTA of $157 \mathrm{~mm}$ ), and a mean $10 \mathrm{~cm}$ soil temperature of $15.6{ }^{\circ} \mathrm{C}$ in July and August.

For the pasture grazing trials, total rainfall for site 1 in May, June, July and August was $355 \mathrm{~mm}$ (LTA over this period was $349 \mathrm{~mm}$ ), with a mean soil temperature of $14.2^{\circ} \mathrm{C}$, while site 2 received $350 \mathrm{~mm}$ of rain in the same period and had a mean soil temperature of $15.3{ }^{\circ} \mathrm{C}\left(\mathrm{LTA}=283 \mathrm{~mm}\right.$ and $\left.15.0{ }^{\circ} \mathrm{C}\right)$.

\subsection{Statistical Analysis}

Statistical analysis was carried out using the XLSTAT statistical software for Microsoft Excel. Where appropriate, tests ranged from a t-test for two independent samples (when comparing the means of two independent groups) to multiple (pair-wise) comparisons using Student-Newman-Kuels (SNK) and/or Tukey's honest significant difference (HSD) test (when comparing three or more independent groups) to the Kruskal-Wallis test (for nonnormal distribution of data). Both one- and two-way ANOVAs for qualitative independent variables and linear regression for quantitative independent variables were used to assess the interaction between factors. In the text, the term 'significant' refers to $p \leq 0.05$.

\section{Results \& Discussion}

\subsection{Nitrogen Response Curve}

A nitrogen response experiment in the lysimeter trials was carried out to correlate the effect of additional $\mathrm{N}$ applications with yield. Figure 1 shows a linear response $\left(\mathrm{R}^{2}=0.97\right)$ between the three applications of $\mathrm{N}$ (\% of $\mathrm{N}$ is related to amounts described in Supplementary Table S2) and total grass yield. At these rates, the typical levelling-off effect of the $\mathrm{N}$ response curve between $\mathrm{N}$ application and crop yield was not reached [26]. Between $75 \%$ 
$\mathrm{N}$ and $100 \% \mathrm{~N}$, there was still a substantial increase in yield of $36 \%$, highlighting the impact of the additional $25 \% \mathrm{~N}$ on grass growth.

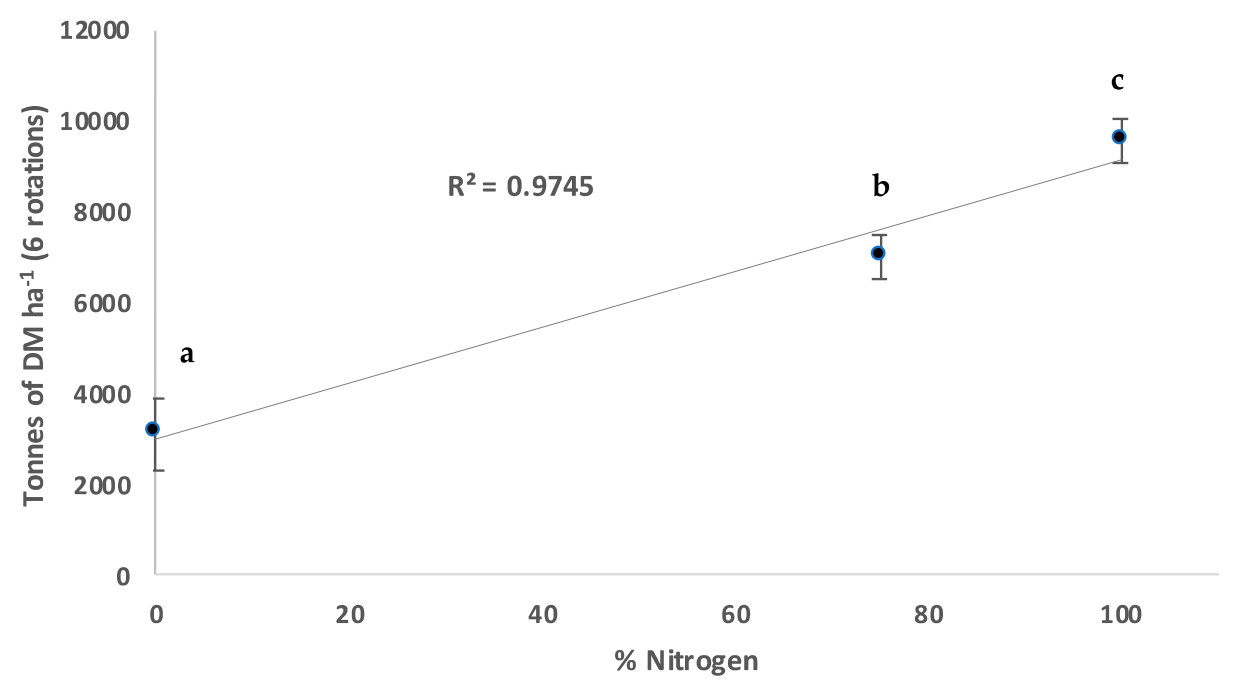

Figure 1. Nitrogen response curve for the modified lysimeter trials. Results are the means $\pm \mathrm{SE}$ $(n=6)$. Significance $(p<0.05)$ is indicated by different letters (Tukey HSD).

\subsection{Modified Lysimeter Grass Growth Yield and Quality Information}

The lysimeter trials ran from June to October in 2020 and from February to August in 2021. Soil fertility ( $\mathrm{pH}, \mathrm{P}$ and $\mathrm{K}$ levels), texture and textural class for the six soils are described in Supplementary Table S2. Weather data are described in Supplementary Table S4. The daily grass growth in terms of dry matter (DM) ha ${ }^{-1}$ for the lysimeter trials is presented in Figure 2, where both the $1 \times$ and $1.5 \times$ rates of PSI-362 significantly increased the yield compared to the $75 \% \mathrm{~N}$ control. There was also a concentration effect evident, as the rate of PSI-362 increased as did the effect on the average daily grass growth per hectare $(0.5 \times=55.3 \mathrm{~kg}, 1 \times=61.9 \mathrm{~kg}$ and $1.5 \times=66 \mathrm{~kg})$. The $1.5 x$ rate of PSI-362 $(@ 75 \% \mathrm{~N})$ out-grew the $75 \% \mathrm{~N}$ control by almost $15.2 \mathrm{~kg}\left(66.0 \mathrm{vs} .50 .8 \mathrm{~kg} \mathrm{ha}^{-1}\right)$ and the $100 \% \mathrm{~N}$ control by $1.2 \mathrm{~kg}\left(64.6 \mathrm{~kg} \mathrm{ha}^{-1}\right)$.

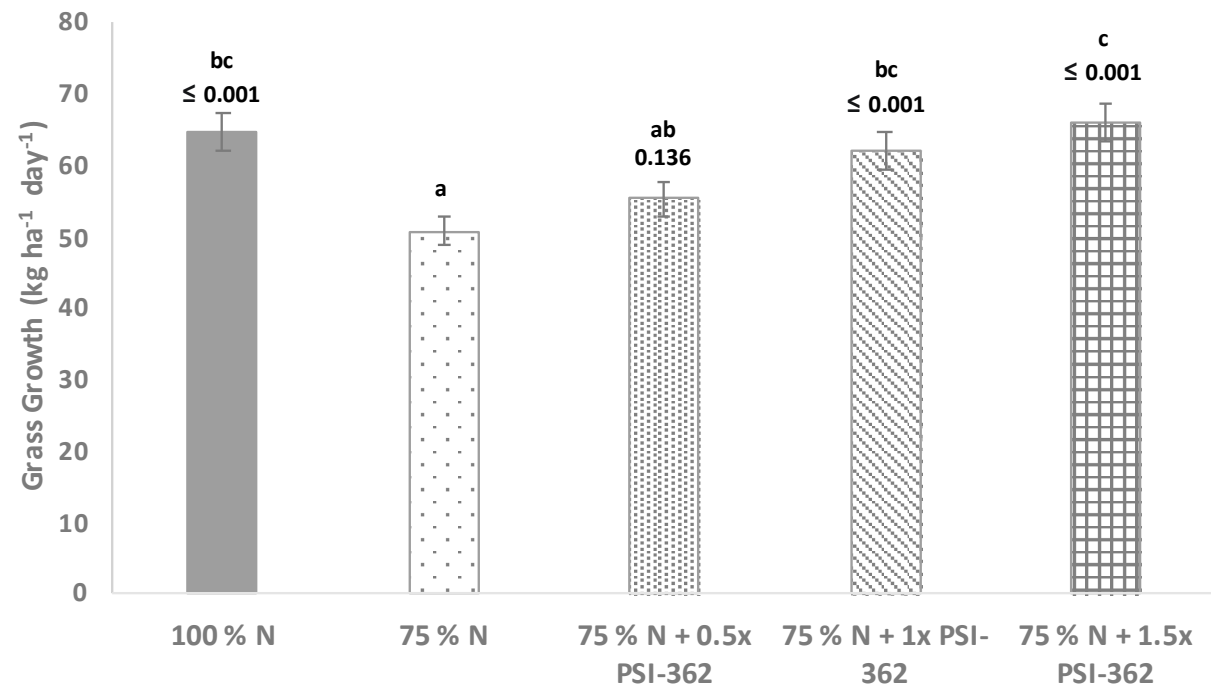

Figure 2. Average grass growth $\left(\mathrm{kg} \mathrm{ha}^{-1} \mathrm{day}^{-1}\right)$ from the lysimeter trials over two years from three replicates of six soils with six rotations per year. $\mathrm{N}=216$. Numbers represent mean $\pm \mathrm{SE}$. Significance is indicated by different letters $(p<0.05)$. $p$ values represent significance levels compared to the $75 \%$ $\mathrm{N}$ control-Tukey HSD. 
Figure 3 presents data on DM, CP and DMD yields of the lysimeter trials across the two years (six rotations/year). The effect of a $25 \%$ reduction in $\mathrm{N}$ was evident in the yields for the two controls $(100 \%$ N vs. $75 \% \mathrm{~N})$, with a $25 \%$ decrease in DM yield ( $\left.\mathrm{kg} \mathrm{DM} \mathrm{ha}^{-1}\right)$, a $29 \%$ decrease in $\mathrm{CP}\left(\mathrm{kg} \mathrm{ha}^{-1}\right)$ per hectare and a $26 \%$ reduction in DMD (kg ha ${ }^{-1}$; Figure $\left.3 \mathrm{~A}-\mathrm{C}\right)$. All PSI-362 rates increased DM, CP and DMD yield over the $75 \% \mathrm{~N}$ control. In addition, these increases were correlated with increasing concentrations of the biostimulant PSI-362 on the coated fertilizer. Increasing the PSI-362 concentration from $0.5 \times$ to $1.0 \times$ to $1.5 \times$ resulted in an increase in DM yield of $9 \%, 24 \%$ and $32 \%$, respectively, over the $75 \% \mathrm{~N}$ control ( $6772 \mathrm{~kg}$ of dry matter ha ${ }^{-1}$; with the $1 \times$ and $1.5 \times$ concentration being significantly different). The $1.5 \times$ rate exceeded the $100 \% \mathrm{~N}$ control by $4 \%$ (Figure $3 \mathrm{~A}$ ): The total dry matter $\left(\mathrm{kg} \mathrm{ha}^{-1}\right)$ of six rotations according to year and soil type from the lysimeter trials is presented in Supplementary Table S5.

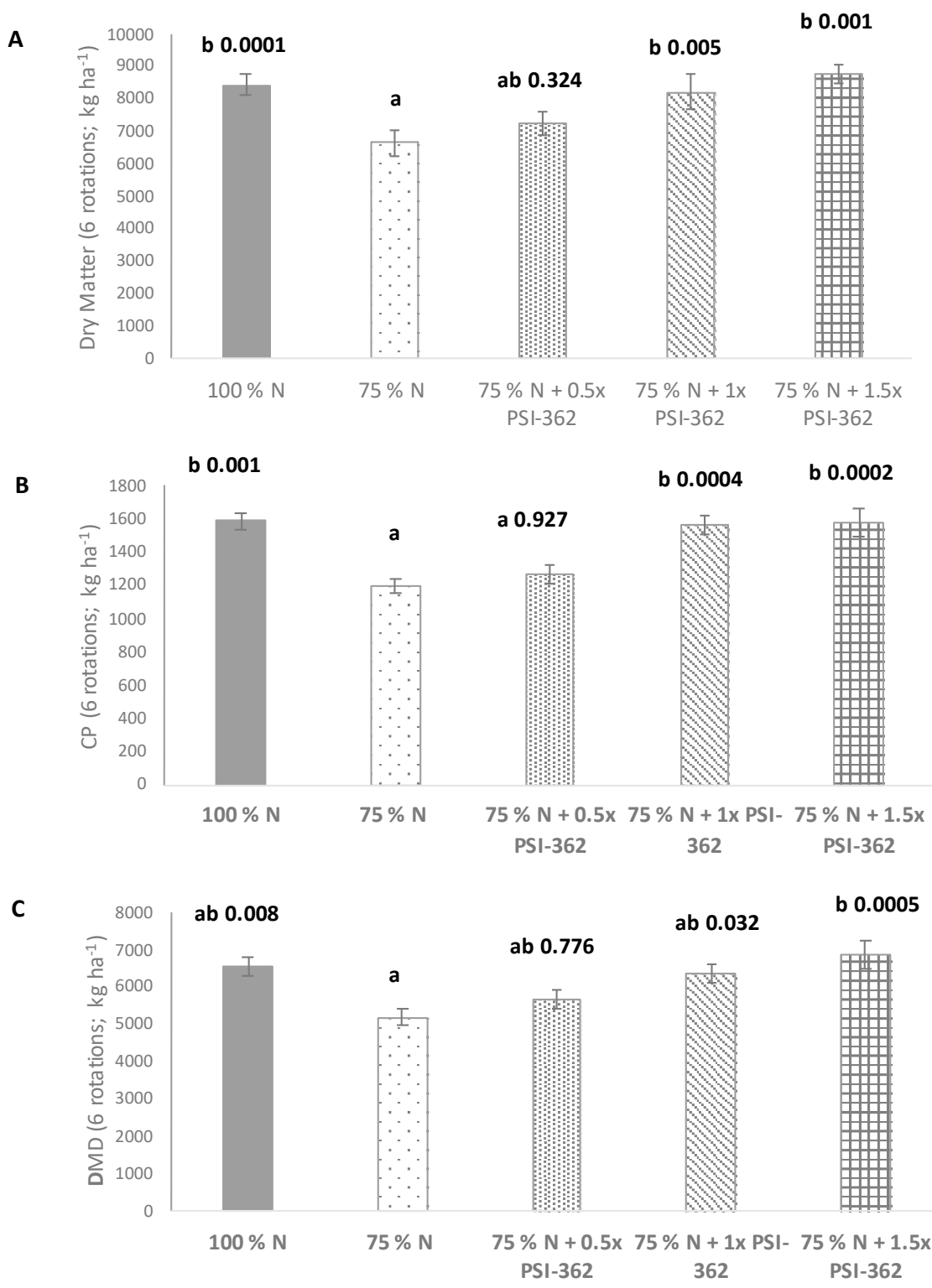

Figure 3. Effects of biostimulant application on the agronomic traits of perennial ryegrass. (A) Results for total yield (DM ha ${ }^{-1}$ ), which is the average of the sum of three replicates over six rotations per year across two years for six different soils, (B) CP ha ${ }^{-1}$ and (C) DMD ha ${ }^{-1}$. Significance is indicated by different letters, while $p$ values represent significance levels compared to the $75 \% \mathrm{~N}$ control (Kruskal -Wallis). Values represent mean \pm SE $(n=36)$. 
The correlation between increasing rates of PSI-362 and 25\% less $\mathrm{N}$ was also evident in the results of the quality parameters measured. The $\mathrm{C} p$ values were dependent of the level of PSI-362 applied, as there were increases of $6 \%, 31 \%$ and $32 \%$ with $0.5 \times, 1.0 \times$ and $1.5 \times$ PSI-362, respectively, over the $75 \%$ control $\left(1197 \mathrm{~kg}\right.$ of $\left.\mathrm{CP} \mathrm{ha}^{-1}\right)$. This suggests that the optimal dose is between the $1 \times$ and $1.5 \times$ concentration due to the levelling off of the response (Figure 3B). Additionally, the DMD ha ${ }^{-1}$ values increased according to the application rate of PSI-362, with $9 \%, 23 \%$ and $32 \%$ increases in yield for $0.5 \times, 1 \times$ and $1.5 \times$ over the $75 \% \mathrm{~N}$ control (5312 $\mathrm{kg}$ of DMD ha $^{-1}$; Figure $3 \mathrm{C}$ ).

The effect of soil type (loam vs. silt-loam), soil $\mathrm{pH}$, soil $\mathrm{P}$ and soil $\mathrm{K}$ level on the performance (DM, CP and DMD yield) with the PSI-362-coated fertilizer is shown in Table 1, while Supplementary Figure S2 highlights the significant difference between the $75 \% \mathrm{~N}$ and $100 \% \mathrm{~N}$ control in terms of DM yield according to soil texture. Analysis of the biomass DM yield showed that only treatment had a significant effect $(p<0.001)$. One-way ANOVA and linear regression analysis of soil type and soil quantitative variables $(\mathrm{pH}, \mathrm{P}$ and $\mathrm{K}$ levels) showed no statistically significant effect on biomass DM yield. A similar result for $\mathrm{CP}$ and DMD yield was observed, with the treatments having a significant effect on these quality parameters $(p \leq 0.001)$.

Table 1. Relationship between treatments (PSI-362-coated fertilizer), soil type (loam or silt-loam), soil $\mathrm{pH}$, soil $\mathrm{P}$ and soil $\mathrm{K}$ levels on DM (biomass dry matter), CP (crude protein) and DMD (digestible dry matter) yield.

\begin{tabular}{|c|c|c|c|}
\hline Factor & DM kg ha ${ }^{-1}$ & CP kg ha ${ }^{-1}$ & DMD kg ha-1 \\
\hline Treatment (T) & $* * *$ & $* * *$ & $* * *$ \\
\hline Soil pH & ns & ns & ns \\
\hline Soil phosphorus $(\mathrm{P})$ & ns & $\mathrm{ns}$ & $\mathrm{ns}$ \\
\hline Soil potassium $(\mathrm{K})$ & ns & ns & ns \\
\hline Soil type (ST) & ns & ns & ns \\
\hline \multicolumn{4}{|l|}{ Treatment $(\mathrm{T})$} \\
\hline $75 \% \mathrm{~N}$ & $6611 a \pm 296$ & $1193 a \pm 45$ & $5299 a \pm 264$ \\
\hline $75 \% N+0.5 \times$ & $7239 a b \pm 377$ & $1269 \mathrm{a} \pm 58$ & $5760 \mathrm{ab} \pm 328$ \\
\hline $75 \% \mathrm{~N}+1 \times$ & $8193 b c \pm 383$ & $1560 \mathrm{~b} \pm 61$ & $6459 b \pm 328$ \\
\hline $75 \% \mathrm{~N}+1.5 \times$ & $8738 c \pm 531$ & $1575 b \pm 84$ & $6946 b \pm 443$ \\
\hline $100 \% \mathrm{~N}$ & $8412 b c \pm 340$ & $1587 \mathrm{~b} \pm 50$ & $6602 b \pm 296$ \\
\hline
\end{tabular}

$\mathrm{ns},{ }^{* * *}$ Non-significant or significant at $p \leq 0.001$, respectively. Different letters indicate statistical differences with $p \leq 0.05$ based on one-way ANOVA for qualitative independent variables and linear regression for quantitative independent variables. Data are the means \pm SE. Number of biological replicates $(n=12)$.

Soil texture is not readily subject to change and is thus considered a basic property [27] in comparison to $\mathrm{pH}$ or $\mathrm{P}$ and $\mathrm{K}$ contents that can be rectified through appropriate agronomic practices. Soil texture will play a significant role in terms of a soil's ability to hold nutrients, with the clay fraction being particularly important as it can impact the colloidal and electrostatic properties of the soil and thus increase the surface area to hold nutrients. Additionally, the water-holding capacity will also vary according to texture, as soils with a lower clay content tend to be more free draining due to the tendency to have a larger pore size, resulting in a greater tendency for nutrients to be washed away and lost as leachate [28]. Soil texture can specifically affect nitrogen loss as nitrate leaching. Van Es et al. found that nitrate leaching was more prevalent in loamy sand soil rather than in clay loam soil (up to 2.5 times greater on maize cropped land) due to higher hydraulic conductivity and lower retentivity [29]. However, the lack of a significant effect in the one-way ANOVA suggests that PSI-362 will perform the same in either soil type.

\subsection{PSI-362 Application Enhanced NUE in Lysimeter Trials}

Application of PSI-362 at $1 \times$ and $1.5 \times$ significantly improved NUE when compared to the $75 \% \mathrm{~N}$ control with a $33 \%$ increase in NUE (Figure 4 ). There was also improved NUE when compared to the $100 \% \mathrm{~N}$ control, with a $17 \%$ increase in NUE, which is perhaps 
unsurprising given the results in $\mathrm{CP} \mathrm{ha}^{-1}$ yield from Figure $3 \mathrm{~B}$ where the differences between the $1 \times$ and $1.5 \times$ rate and the $100 \% \mathrm{~N}$ control were negligible, despite the PSI362 treatment receiving $25 \%$ less N. Biostimulants of many different classes have been reported to improve NUE (and indeed other nutrient use efficiencies). Previous authors have reported enhanced NUE in baby lettuce and spinach with a seaweed extract from Ecklonia maxima, but no specific data related to $\mathrm{N}$ metabolism were reported [16]. In baby lettuce, increases in yield of between $6 \%$ and $14 \%$ were observed depending on the nitrogen regime. This increased NUE may be attributed to the phytochemical efficiency and a better activation of photosystem 2 (as seen by the increase in chlorophyll for baby lettuce), while in spinach, ascorbic acid and polyphenol levels were significantly increased. Augmentation of these secondary metabolites has been implicated in key enzyme activities such as the enzyme chalcone isomerase (associated with phytochemical homeostasis through the synthesis of flavanone precursors). Rouphael et al. [16] also found increases in polyphenols, ascorbic acid and the SPAD index in spinach grown under glasshouse conditions using seaweed extracts from Ecklonia maxima and Ascophyllum nodosum combined with vegetal oils and herbal extracts. This report also found that the nitrate content was significantly enhanced in seaweed extract-treated plants, a finding similar to that reported by Goñi et al. [19] using PSI-362-coated fertilizer under both high and low nitrogen regimes in barley. This increased nitrate content may be associated with enhanced nitrogen uptake as seen with the significantly increased expression of NRT1.1, NRT2.1 and NRT1.5 genes, while the enhanced amino acid profile may be due to increased enzymatic activity in the form of nitrate reductase and glutamate synthase, both key enzymes in the plant N cycle. SiwikZiomek and Szczepanek found that a commercial seaweed biostimulant increased nitrogen concentration in the whole plant of oilseed rape at all development stages; however, at the fruit development stage, this effect was linked to the application of sulphur [30]. In the same crop, an Ascophyllum nodosum extract was found to increase the expression of genes encoding $\mathrm{N}$ metabolism in oilseed rape that resulted in a $115 \%$ and $21 \%$ increase in nitrogen uptake in the roots and shoots, respectively [31].

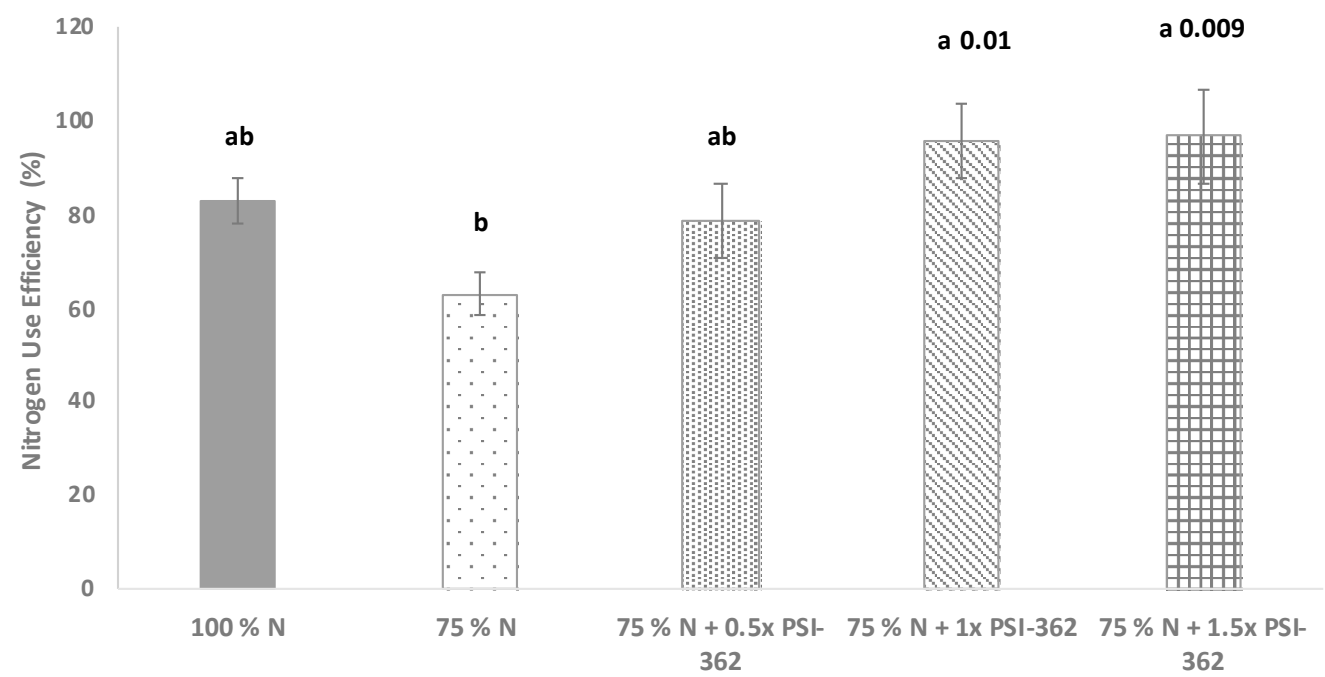

Figure 4. Calculated nitrogen use efficiency (NUE) values from the lysimeter trials. $p$ values represent significance levels compared to the $75 \% \mathrm{~N}$ control (Tukey HSD). Values represent mean $\pm \mathrm{SE}(n=6)$.

\subsection{Silage Harvesting Trials}

The silage harvesting field trials took place in 2020 and 2021 across 11 sites. For trials in 2020, PSI-362 was coated on a commercial CAN product (27\% N + 4\% S), while for 2021 trials, PSI-362 was coated on compound fertilizer (N-P-K; 20-2-12 + 3\% S), with the relative amount described in Supplementary Table S3. The results of DM, CP and DMD yield from all 11 trials are shown in Table 2, while Table 3 categorizes the trials as either first (May/June), second (July) or third harvests (August). Supplementary Table S6 provides 
the dry matter $\left(\mathrm{kg} \mathrm{ha}^{-1}\right)$ values for the individual farms from the silage trials. Results from all 11 sites showed that there was no significant loss in DM yield between 100\% $\mathrm{N}$ and $80 \% \mathrm{~N}+$ PSI-362 (4508 $\mathrm{kg} \mathrm{ha}^{-1}$ vs. $\left.4594 \mathrm{~kg} \mathrm{ha}^{-1}\right), \mathrm{CP}$ content $\left(840 \mathrm{~kg} \mathrm{ha}^{-1}\right.$ vs. $847 \mathrm{~kg} \mathrm{ha}^{-1}$ ) or DMD (3352 $\mathrm{kg} \mathrm{ha}^{-1}$ vs. $3426 \mathrm{~kg} \mathrm{ha}^{-1}$ ) despite a $20 \%$ reduction in $\mathrm{N}$ for the PSI-362-coated fertilizer regime (Table 2 ). The dry matter digestibility is a key quality trait of all forages [32]; it is the proportion of forage that can be digested by the ruminant and comprises the crude protein, carbohydrates and lipids. Digestibility is linked to the energy of the forage and ultimately the performance of the animal; increases in DMD lead to increased milk yield or carcass gain in bovines. Variations in digestibility in grass and ultimately silage can range from sward type to harvesting date and fertilizer application. $\mathrm{CP}$ is another important quality trait for forages and is often the most expensive component of livestock concentrate rations [33]. Similar to DMD, CP levels in grass and silage will depend on sward type, $\mathrm{N}$ application and harvesting/grazing date. The total \% DMD and $\mathrm{CP}$ was found to be $74 \%$ and $18.6 \%$, respectively, in the $100 \% \mathrm{~N}$ control and $75 \%$ and $18.4 \%$, respectively, in the $80 \% \mathrm{~N}+$ PSI-362 treated sites (these results are the average DMD and $\mathrm{CP}$ as a $\%$, for all silage harvesting trials; $n=11$ ). The PSI-362-treated grass silage crop showed no DM yield penalties or quality loss with a significant reduction in $\mathrm{N}$ fertilizer. The DMD and CP values would be considered excellent at harvesting and will likely result in good quality silage.

Table 2. Summary of results for dry matter (DM), crude protein (CP) and digestible dry matter (DMD) yields from the 11 grass silage field trials over two years, 2020 and 2021.

\begin{tabular}{|c|c|c|c|c|c|c|}
\hline Regime & $\begin{array}{c}\text { Yield } \\
\left(\text { kg DM ha }^{-1}\right)\end{array}$ & $p$ Value & $\begin{array}{c}\text { CP } \\
\left(\mathrm{kg} \mathrm{DM} \mathrm{ha} \mathbf{a}^{-1}\right)\end{array}$ & $p$ Value & $\begin{array}{c}\text { DMD } \\
(\mathrm{kg} \mathrm{DM} \mathrm{ha-1)}\end{array}$ & $p$ Value \\
\hline $\begin{array}{c}100 \% \mathrm{~N} \\
80 \% \mathrm{~N}+\mathrm{PSI}-362\end{array}$ & $\begin{array}{l}4508 \pm 192 \\
4594 \pm 225\end{array}$ & 0.775 & $\begin{array}{l}840 \pm 80 \\
847 \pm 68\end{array}$ & 0.948 & $\begin{array}{l}3352 \pm 300 \\
3426 \pm 359\end{array}$ & 0.878 \\
\hline
\end{tabular}

Values represent the mean $\pm \mathrm{SE}(n=11) . p$ values were determined using a two-sample $t$-test.

Table 3. DM, DMD and CP yield from 1st, 2nd and 3rd harvests of silage trials.

\begin{tabular}{|c|c|c|c|c|c|c|c|}
\hline Harvest & Regime & $\begin{array}{c}\text { DM Yield } \\
\left(\mathrm{kg} \mathrm{DM} \mathrm{ha}^{-1}\right)\end{array}$ & $p$ Value & $\begin{array}{c}\text { CP } \\
\left(\mathrm{kg} \mathrm{DM} \mathrm{ha}^{-1}\right)\end{array}$ & $p$ Value & $\begin{array}{c}\text { DMD } \\
\left(\mathrm{kg} \mathrm{DM} \mathrm{ha}^{-1}\right)\end{array}$ & $p$ Value \\
\hline $1 \mathrm{st}$ & $\begin{array}{c}100 \% \mathrm{~N} \\
80 \% \mathrm{~N}+\mathrm{PSI}-362\end{array}$ & $\begin{array}{l}5325 \pm 275 \\
5485 \pm 365\end{array}$ & 0.760 & $\begin{array}{l}1031 \pm 86 \\
1013 \pm 61\end{array}$ & 0.884 & $\begin{array}{l}4142 \pm 259 \\
4387 \pm 235\end{array}$ & 0.557 \\
\hline 2nd & $\begin{array}{c}100 \% \mathrm{~N} \\
80 \% \mathrm{~N}+\mathrm{PSI}-362\end{array}$ & $\begin{array}{l}3986 \pm 500 \\
4182 \pm 321\end{array}$ & 0.767 & $\begin{array}{l}738 \pm 65 \\
800 \pm 68\end{array}$ & 0.580 & $\begin{array}{l}2941 \pm 381 \\
3154 \pm 243\end{array}$ & 0.672 \\
\hline 3rd & $\begin{array}{c}100 \% \mathrm{~N} \\
80 \% \mathrm{~N}+\mathrm{PSI}-362 \\
100 \% \mathrm{~N}+\mathrm{PSI}-362\end{array}$ & $\begin{array}{l}4217 \pm 631 \\
4124 \pm 595 \\
4727 \pm 873\end{array}$ & $\begin{array}{l}\mathrm{a} \\
\mathrm{a} \\
\mathrm{a}\end{array}$ & $\begin{array}{c}797 \pm 49 \\
746 \pm 44 \\
1064 \pm 98\end{array}$ & $\begin{array}{l}\mathrm{a} \\
\mathrm{a} \\
\mathrm{b}\end{array}$ & $\begin{array}{l}3217 \pm 196 \\
3134 \pm 185 \\
3328 \pm 307\end{array}$ & $\begin{array}{l}\mathrm{a} \\
\mathrm{a} \\
\mathrm{a}\end{array}$ \\
\hline
\end{tabular}

1st-cut silage trials from $2021(n=2)$. 2nd-cut silage trials from 2021 from three separate sites $(n=5)$. 3rd-cut silage trials from $2020(n=5)$ and $2021(n=1)$. Note for the 100\% control, $n=6 ; 80 \% \mathrm{~N}+$ PSI-362, $n=6 ; 100 \% \mathrm{~N}+$ PSI-362, $n=4$. Significance by multiple comparison analysis is indicated by different letters for 3rd-cut silage trials; Tukey HSD—significance $p<0.05$. Values represent the mean $\pm \mathrm{SE}$.

In terms of silage harvesting, total DM yields were marginally improved for both 1stand 2nd-cut trials with PSI-362 treatment (3\% and 5\%, respectively), with this improvement under reduced $\mathrm{N}$ treated sites continuing with total DMD ha -1 (6\% and 7\%). Both yield and DMD were slightly below those for the $100 \% \mathrm{~N}$ control for the 3rd harvest $(-2 \%$ and $-3 \%$, respectively) although this reduction was not significant ( $p=0.96$ and 0.94 , respectively). For 1st, 2 nd and 3rd cuts, total $\mathrm{CP}$ ha- 1 showed variable results $(-2 \%,+8 \%$ and $-6 \%$ ) across the harvests when compared to the $100 \% \mathrm{~N}$ control. A positive control was also included for the 3rd-cut silage trials in 2020 (100\% N and PSI-362) where there were increases in yield and DMD along with a significant increase in CP ha -1 of $12 \%, 3 \%$ and $34 \%$, respectively (Table 3 ). 


\subsection{Pasture Grazing Field Trials}

The pasture grazing trials took place at two sites in 2021. There were 18 replicates per treatment with five grazings per replicate for site 1 and two replicates with five grazings per replicate for site 2 . There were no significant differences in daily grass growth and DMD for grazing site 1 between PSI-362-coated fertilizer $(75 \% \mathrm{~N})$ and the $100 \% \mathrm{~N}$ control (Table 4). However, the results showed a $12 \%$ increase in CP with the application of PSI-362coated fertilizer $\left(13.2 \mathrm{~kg} \mathrm{ha}^{-1}\right.$ vs. $\left.14.8 \mathrm{~kg} \mathrm{ha}^{-1}\right)$, although this increase was not statistically significant. At grazing site 2, the PSI-362-coated CAN fertilizer with $25 \%$ less $\mathrm{N}$ achieved an $8 \%$ increase in daily growth of grass versus the $100 \% \mathrm{~N}$ control, with daily growth figures of $92.4 \mathrm{~kg} \mathrm{DM} \mathrm{ha}^{-1}$ vs. $99.4 \mathrm{~kg} \mathrm{DM} \mathrm{ha}^{-1}$. Individual site, rotation and plot data is presented in Supplementary Table S7.

Table 4. Daily grass growth (DGG), DMD and CP for the pasture grazing trials.

\begin{tabular}{|c|c|c|c|c|c|c|c|}
\hline Site & Regime & $\begin{array}{c}\text { DGG } \\
\left(\mathrm{kg} \mathrm{DM} \mathrm{ha}^{-1} \text { Day }^{-1}\right)\end{array}$ & $p$ Value & $\begin{array}{c}\text { DMD } \\
\left(\mathrm{kg} \mathrm{ha}^{-1} \mathrm{Day}^{-1}\right)\end{array}$ & $p$ Value & $\begin{array}{c}\text { CP } \\
\left(\mathrm{kg} \mathrm{ha}^{-1} \text { Day }^{-1}\right)\end{array}$ & $p$ Value \\
\hline 1 & $\begin{array}{c}100 \% \mathrm{~N} \\
75 \% \mathrm{~N}+\mathrm{PSI}-362\end{array}$ & $\begin{array}{r}60.9 \pm 2.5 \\
59.3 \pm 2.4\end{array}$ & 0.629 & $\begin{array}{l}47.2 \pm 1.9 \\
46.3 \pm 1.9\end{array}$ & 0.132 & $\begin{array}{l}13.2 \pm 0.5 \\
14.8 \pm 0.6\end{array}$ & 0.45 \\
\hline 2 & $\begin{array}{c}100 \% \text { N (PU) } \\
75 \% \text { N + PSI-362 }\end{array}$ & $\begin{array}{l}92.4 \pm 11.8 \\
99.4 \pm 11.6\end{array}$ & 0.679 & $\begin{array}{l}\text { ND } \\
\text { ND }\end{array}$ & $\mathrm{N} / \mathrm{A}$ & $\begin{array}{l}\text { ND } \\
\text { ND }\end{array}$ & $\mathrm{N} / \mathrm{A}$ \\
\hline
\end{tabular}

$n=17$ for pasture site 1 with five grazings per replicate, $n=2$ for pasture site 2 with five grazings per replicate, $\mathrm{PU}=$ protected urea, Values represent the mean $\pm \mathrm{SE}, p$ values were determined using the two sample $t$-test, $\mathrm{ND}=$ not determined, $\mathrm{N} / \mathrm{A}=$ not applicable.

Maintaining or even improving grass yield or quality under a reduced $\mathrm{N}$ regime has many benefits in terms of animal performance, farm economics and a reduced environmental impact. Efficiencies in a grass-based production system for beef and dairy are underpinned by producing quality grass, thus negating the need to supplement feeding with expensive concentrates [34,35]. These efficiencies not only lead to economic benefits but also environmental benefits. Nationally in Ireland, where grass-based systems are the predominant type of system for ruminants, the farm gate NUE is $36.7 \%$ [33]. The potential to reduce nitrogen fertilizer input while maintaining yields would enhance these farm gate efficiencies, along with the agronomic NUE.

\section{Conclusions}

Improved NUE of crops will result in reduced fertilizer input while maintaining crop yield and farm wide productivity. Through the application of a granular fertilizer coated with a biostimulant (PSI-362), specifically developed to enhance NUE, it was possible to reduce $\mathrm{N}$ input in grassland by 20 to $25 \%$ while maintaining yield and/or quality (in terms of dry matter digestibility and crude protein) in comparison to the $100 \% \mathrm{~N}$ control across different soil types and relevant agronomic systems. Overall, PSI-362 displayed an improved NUE of $17 \%$ over the $100 \% \mathrm{~N}$ control. Further studies to evaluate the performance of biostimulant technologies for improving NUE are required in order to demonstrate the robustness of the performance across different geographies, climates and pasture production systems. The European Commission's Biodiversity Strategy (as described by the European Green Deal) for 2030 sets out specific targets with regard to fertilizer, including a $20 \%$ reduction in fertilizer use by reducing fertilizer losses by $50 \%$ [36]. By incorporating biostimulant technologies, such as that reported here, into mainstream agricultural practice, a $20 \%$ reduction in $\mathrm{N}$ fertilizer can be achieved without losses in crop yield, quality and overall agricultural productivity.

Supplementary Materials: The following are available online at https:/ / www.mdpi.com/article / 10.3390/agronomy12020463/s1, Supplementary Figure S1: Modified lysimeter set-up, Supplementary Figure S2: Performance of PSI-362-coated fertilizer sorted according to soil type. Supplementary Table S1: Soil attributes from the six different soils used for the modified lysimeter trials; Supplementary Table S2: The fertilizer regime applied to the modified lysimeter trials; Supplemen- 
tary Table S3: Fertilizer regime, soil fertility (P and K) index and coordinates of the 2020 and 2021 field trials; Supplementary Table S4: Weather Data for lysimeter and field trials; Supplementary Table S5: Total dry matter $\left(\mathrm{kg} \mathrm{ha}^{-1}\right)$ of six rotations according to year and soil type from the lysimeter trials; Supplementary Table S6: Dry matter $\left(\mathrm{kg} \mathrm{ha}^{-1}\right)$ values for the individual farms from the silage trials; Supplementary Table S7: Daily grass growth $\left(\mathrm{kg} \mathrm{DM} \mathrm{ha}^{-1} \mathrm{day}^{-1}\right)$ for the two pasture grazing sites.

Author Contributions: Conceptualization, P.Q., A.C., E.F., J.K., C.K.-Y.N. and S.O.; methodology, P.Q., A.C. and E.F.; software, P.Q. and S.O.; validation, P.Q., A.C., E.F., J.K., C.K.-Y.N. and S.O.; formal analysis, P.Q., A.C., E.F., J.K., C.K.-Y.N. and S.O.; investigation, P.Q., A.C. and E.F.; resources, P.Q., A.C., E.F., J.K., C.K.-Y.N. and S.O.; data curation, P.Q., A.C., E.F. and S.OC.; writing-original draft preparation, P.Q., C.K.-Y.N. and S.O.; writing-review and editing, P.Q., A.C., E.F., J.K., C.K.-Y.N. and S.O.; visualization, P.Q., A.C., E.F., J.K., C.K.-Y.N. and S.O.; supervision, J.K., C.K.-Y.N. and S.O.; project administration, A.C., C.K.-Y.N. and S.O.; funding acquisition, P.Q., C.K.-Y.N. and S.O. All authors have read and agreed to the published version of the manuscript.

Funding: This research has been conducted with the assistance of funding from the Continued Professional Development programme from MTU Kerry. This funder provided support in the form of a scholarship for the author P.Q.

Institutional Review Board Statement: Not applicable.

Informed Consent Statement: Not applicable.

Data Availability Statement: The datasets generated for this study are available on request from the corresponding authors.

Acknowledgments: The authors would like to acknowledge the farmers who provided access to grasslands and for their cooperation in carrying out the silage and grazing field trials. In addition, Oscar Goñi is thanked for his assistance with the statistical analysis.

Conflicts of Interest: Author A.C. was employed by the company Grennans \& Sons. Authors E.F. and S.O. were employed by the company Brandon Bioscience. The remaining authors (P.Q., J.K. and C.K.-Y.N.) declare that the research was conducted in the absence of any commercial or financial relationships that could be construed as a potential conflict of interest. The funder (MTU Kerry) and Brandon Bioscience had no role in the design of the study; in the collection, analyses, or interpretation of data; in the writing of the manuscript, or in the decision to publish the results. The authors declare no conflict of interest.

\section{References}

1. Wall, D.; Plunkett, M. Major and Micro Nutrient Advice for Productive Agricultural Crops; Teagasc, Environment Research, Centre Johnstown Castle: Wexford, Ireland, 2021.

2. World Health Organization. Musculoskeletal Conditions. Available online: https://www.who.int/news-room/fact-sheets/ detail/musculoskeletal-conditions (accessed on 15 December 2021).

3. Hoxha, A.; Christensen, B. The carbon footprint of fertiliser production: Regional reference values. In Proceedings-International Fertiliser Society; International Fertiliser Society: Colchester, UK, 2019.

4. Barak, P.; Jobe, B.O.; Krueger, A.R.; Peterson, L.A.; Laird, D.A. Effects of long-term soil acidification due to nitrogen fertilizer inputs in Wisconsin. Plant Soil 1997, 197, 61-69. [CrossRef]

5. Banger, K.; Nasielski, J.; Janovicek, K.; Sulik, J.; Deen, B. Potential Farm-Level Economic Impact of Incorporating Environmental Costs into Nitrogen Decision Making: A Case Study in Canadian Corn Production. Front. Sustain. Food Syst. 2020, 4, 96. [CrossRef]

6. Sigurdarson, J.J.; Svane, S.; Karring, H. The molecular processes of urea hydrolysis in relation to ammonia emissions from agriculture. Rev. Environ. Sci. Bio./Technol. 2018, 17, 241-258. [CrossRef]

7. Maraseni, T.N.; Qu, J. An international comparison of agricultural nitrous oxide emissions. J. Clean. Prod. 2016, 135, 1256-1266. [CrossRef]

8. Brentrup, F.; Pallière, C. Nitrogen use efficiency as an agro-environmental indicator. In Proceedings of the OECD Workshop on Agri-environmental Indicators, Leysin, Switzerland, 23-26 March 2010.

9. Dobermann, A.R. Nitrogen Use Efficiency-State of the Art; Agronomy-Faculty Publications, University of Nebraska: Lincoln, NE, USA, 2005; p. 316.

10. van Bueren, E.T.L.; Struik, P.C. Diverse concepts of breeding for nitrogen use efficiency. A review. Agron. Sustain. Dev. 2017, 37,50 .

11. Mitra, G.N. Regulation of Nutrient Uptake by Plants; Springer Science and Business Media LLC: New Delhi, India, 2015; Volume 10, pp. 978-981. 
12. Gebremichael, A.W.; Rahman, N.; Krol, D.J.; Forrestal, P.J.; Lanigan, G.J.; Richards, K.G. Ammonium-Based Compound Fertilisers Mitigate Nitrous Oxide Emissions in Temperate Grassland. Agronomy 2021, 11, 1712. [CrossRef]

13. Long, F.N.J.; Kennedy, S.J.; Gracey, H.I. Effect of fertilizer nitrogen rate and timing on herbage production and nitrogen use efficiency for first-cut silage. Grass Forage Sci. 1991, 46, 231-237. [CrossRef]

14. Ricci, M.; Tilbury, L.; Daridon, B.; Sukalac, K. General Principles to Justify Plant Biostimulant Claims. Front. Plant Sci. 2019, 10, 494. [CrossRef]

15. Du Jardin, P. Plant biostimulants: Definition, concept, main categories and regulation. Sci. Hortic. 2015, 196, 3-14. [CrossRef]

16. Rouphael, Y.; Colla, G. Editorial: Biostimulants in Agriculture. Front. Plant Sci. 2020, 11, 40. [CrossRef]

17. De Pascale, S.; Rouphael, Y.; Colla, G. Plant biostimulants: Innovative tool for enhancing plant nutrition in organic farming. Eur. J. Hortic. Sci. 2018, 82, 277-285. [CrossRef]

18. Innovation Union. Communication from the Commission to the European Parliament, the Council, the European Economic and Social Committee and the Committee of the Regions. In A New Skills Agenda for Europe; Innovation Union: Brussels, Belgium, 2014.

19. Goñi, O.; Łangowski, Ł.; Feeney, E.; Quille, P.; O'Connell, S. Reducing Nitrogen Input in Barley Crops While Maintaining Yields Using an Engineered Biostimulant Derived from Ascophyllum nodosum to Enhance Nitrogen Use Efficiency. Front. Plant Sci. 2021, 12, 789. [CrossRef]

20. Kroetsch, D.; Wang, C. Particle size distribution. Soil Sampl. Methods Anal. 2008, 2, 713-725.

21. Shoemaker, H.E.; McLean, E.O.; Pratt, P.F. Buffer Methods for Determining Lime Requirement of Soils with Appreciable Amounts of Extractable Aluminum. Soil Sci. Soc. Am. J. 1961, 25, 274-277. [CrossRef]

22. Curran, J.; Delaby, L.; Kennedy, E.; Murphy, J.; Boland, T.; O’Donovan, M. Sward characteristics, grass dry matter intake and milk production performance are affected by pre-grazing herbage mass and pasture allowance. Livest. Sci. 2010, 127, 144-154. [CrossRef]

23. O'Donovan, M.; Dillon, P.; Rath, M.; Stakelum, G. Nitrogen use efficiency and apparent nitrogen recovery of Kentucky bluegrass, smooth bromegrass, and orchardgrass. Agron. J. 2002, 94, 421-428.

24. Zemenchik, R.A.; Albrecht, K.A. A comparison of four methods of herbage mass estimation. Ir. J. Agric. Food Res. 2002, 94, 17-27.

25. Hanrahan, L.; Geoghegan, A.; O’Donovan, M.; Griffith, V.; Ruelle, E.; Wallace, M.; Shalloo, L. PastureBase Ireland: A grassland decision support system and national database. Comput. Electron. Agric. 2017, 136, 193-201. [CrossRef]

26. Noor, M.A.; Nawaz, M.M.; Hassan, M.U.; Sher, A.; Shah, T.; Abrar, M.M.; Ashraf, U.; Fiaz, S.; Basahi, M.A.; Ahmed, W.; et al. Small Farmers and Sustainable N and P Management: Implications and Potential Under Changing Climate. In Carbon and Nitrogen Cycling in Soil; Springer Science and Business Media LLC: New York, NY, USA, 2019; pp. 185-219.

27. Brady, N.C.; Weil, R.R.; Brady, N.C. Elements of the Nature and Properties of Soils; Pearson AG: New York, NY, USA, 2010.

28. Ashman, M.; Puri, G. Essential Soil Science: A Clear and Concise Introduction to Soil Science; John Wiley \& Sons: Hoboken, NJ, USA, 2013.

29. Van Es, H.M.; Sogbedji, J.M.; Schindelbeck, R.R. Effect of Manure Application Timing, Crop, and Soil Type on Nitrate Leaching. J. Environ. Qual. 2006, 35, 670-679. [CrossRef]

30. Siwik-Ziomek, A.; Szczepanek, M. Soil Extracellular Enzyme Activities and Uptake of N by Oilseed Rape Depending on Fertilization and Seaweed Biostimulant Application. Agronomy 2019, 9, 480. [CrossRef]

31. Jannin, L.; Arkoun, M.; Etienne, P.; Laîné, P.; Goux, D.; Garnica, M.; Fuentes, M.; Francisco, S.S.; Baigorri, R.; Cruz, F.; et al. Brassica napus Growth is Promoted by Ascophyllum nodosum (L.) Le Jol. Seaweed Extract: Microarray Analysis and Physiological Characterization of N, C, and S Metabolisms. J. Plant Growth Regul. 2013, 32, 31-52. [CrossRef]

32. Hurley, M.; Lewis, E.; Beecher, M.; Garry, B.; Fleming, C.; Boland, T.; Hennessy, D. Dry Matter Intake and In Vivo Digestibility of Grass-Only and Grass-White Clover in Individually Housed Sheep in Spring, Summer and Autumn. Animals 2021, 11, 306. [CrossRef] [PubMed]

33. Buckley, C.; Wall, D.P.; Moran, B.; Murphy, P.N.C. Developing the EU Farm Accountancy Data Network to derive indicators around the sustainable use of nitrogen and phosphorus at farm level. Nutr. Cycl. Agroecosyst. 2015, 102, 319-333. [CrossRef]

34. Finneran, E.; Crosson, P.; O'kiely, P.; Shalloo, L.; Forristal, D.; Wallace, M. Simulation modelling of the cost of producing and utilising feeds for ruminants on Irish farms. J. Farm Manag. 2010, 14, 95-116.

35. Hanrahan, L.; McHugh, N.; Hennessy, T.; Moran, B.; Kearney, R.; Wallace, M.; Shalloo, L. Factors associated with profitability in pasture-based systems of milk production. J. Dairy Sci. 2018, 101, 5474-5485. [CrossRef]

36. Montanarella, L.; Panagos, P. The relevance of sustainable soil management within the European Green Deal. Land Use Policy 2021, 100, 104950. [CrossRef] 